\title{
Endovascular Thrombectomy of COVID-19-Related Large Vessel Occlusion: A Systematic Review and Summary of the Literature
}

\author{
Anas S. Al-Smadi ${ }^{1} \cdot J_{0 h n}$ C. Mach $^{1}$ (D) $\cdot$ Srishti Abrol $^{1} \cdot$ Ali Luqman $^{2} \cdot$ \\ Parthasarathi Chamiraju $^{2} \cdot$ Hani Abujudeh ${ }^{1}$
}

Accepted: 5 February 2021/Published online: 8 March 2021

(C) The Author(s), under exclusive licence to Springer Science+Business Media, LLC part of Springer Nature 2021

\begin{abstract}
Purpose Despite an overall reduction in the number of stroke cases presenting to hospitals during the COVID-19 pandemic, a remarkably high incidence of acute cerebrovascular disease associated with the infection has been reported. In this systematic review, we assess the neurological outcomes and complications of endovascular thrombectomy (EVT) for large vessel occlusions (LVO) in COVID-19 patients.

Methods A literature search was performed in PubMed from December 1, 2019 through September 1st, 2020 using different combinations of suitable keywords. Ten studies reporting EVT outcomes and complications were identified. Two studies that included non-LVO pathologies and COVID-19 negative patients with the outcomes analysis were excluded. Patient demographics, comorbidities, anatomic thrombus location, neurological and angiographic outcomes were assessed.

Results A total of 8 studies, in addition to our institutional case series, were ultimately included in this review. The mean age was 62.2 years, of which $67.6 \%$ were males. M1 segment involvement was the most commonly reported (53.8\%) thrombus location. The mean NIHSS at
\end{abstract}

This article is part of the Topical collection on Quality and Safety.

John C. Mach

john.charles.mach@gmail.com

Hani Abujudeh

HAbujude@dmc.org

1 Department of Radiology, School of Medicine, Wayne State University/Detroit Medical Center, 4201 St. Antoine, DRH, 3L-8, Detroit, MI 48201, USA

2 Department of Neurosurgery, Wayne State University/Detroit Medical Center, Detroit, MI, USA presentation was 20.4 with no significant change at $24 \mathrm{~h}$. Successful revascularization (TICI $\geq 2 \mathrm{~b}$ ) was achieved in $89 \%$. Early proximal cerebral re-occlusion was reported in 6 patients $(11 \%)$ and cerebral hemorrhage in 3 patients (4\%). In hospital mortality was reported in 15 patients $(28.8 \%)$.

Conclusion Despite angiographically successful EVT of LVOs in the majority of patients, this literature analysis demonstrates overall poor outcomes and high mortality in COVID-19 patients post EVT. An unusual incidence of early intracerebral proximal arterial re-occlusion was notable.

Keywords Endovascular thrombectomy · SARS-cov-2 . COVID-19 · Ischemic stroke

\section{Introduction}

Severe acute respiratory syndrome coronavirus 2 (SARSCov-2) is a new strain of the coronavirus family that emerged in 2019 and was first reported in Wuhan, China, but spread exponentially to become a worldwide pandemic in months. Infection with SARS-Cov-2 primarily presents as a severe acute respiratory illness in human subjects [1].

Understanding of the 2019-coronavirus disease (COVID-19) has evolved significantly over time. In addition to respiratory symptoms, COVID-19 may present with various gastrointestinal, renal, neurological and cardiovascular symptoms [2, 3]. Attention has been drawn recently to the thromboembolic sequelae of this disease, including ischemic strokes, due to the severe outcomes associated with these complication [4-6]. Despite a significant overall reduction in the number of stroke cases presenting to hospitals during the pandemic, studies have 
demonstrated a remarkably high incidence of acute cerebrovascular disease in those with COVID-19 [7-9].

Although the indications for endovascular thrombectomy (EVT) of COVID-19 related large vessel occlusions (LVOs) are the same as for the general population, a protected code stroke algorithm has been introduced to expedite management while also ensuring the safety of healthcare providers [10-12]. In this study, we employed meta-analytic techniques to pool data from the literature to explore the outcomes and potential complications of EVT among COVID-19 patients.

\section{Methods}

\section{Institutional Case Series Study Design}

Institutional review board approval was obtained for a retrospective study of COVID-19 positive patients with large vessel occlusions (LVO) who underwent endovascular intervention between March 1 and June 20. Informed consent was waived. We studied patients' demographics, clinical presentations, laboratory findings, National Institutes of Health Stroke Scale (NIHSS), CT angiography (CTA) and CT perfusion (CTP) findings, mechanical thrombectomy procedure, immediate post-procedural outcome and neurological outcome at final follow-up whenever available.
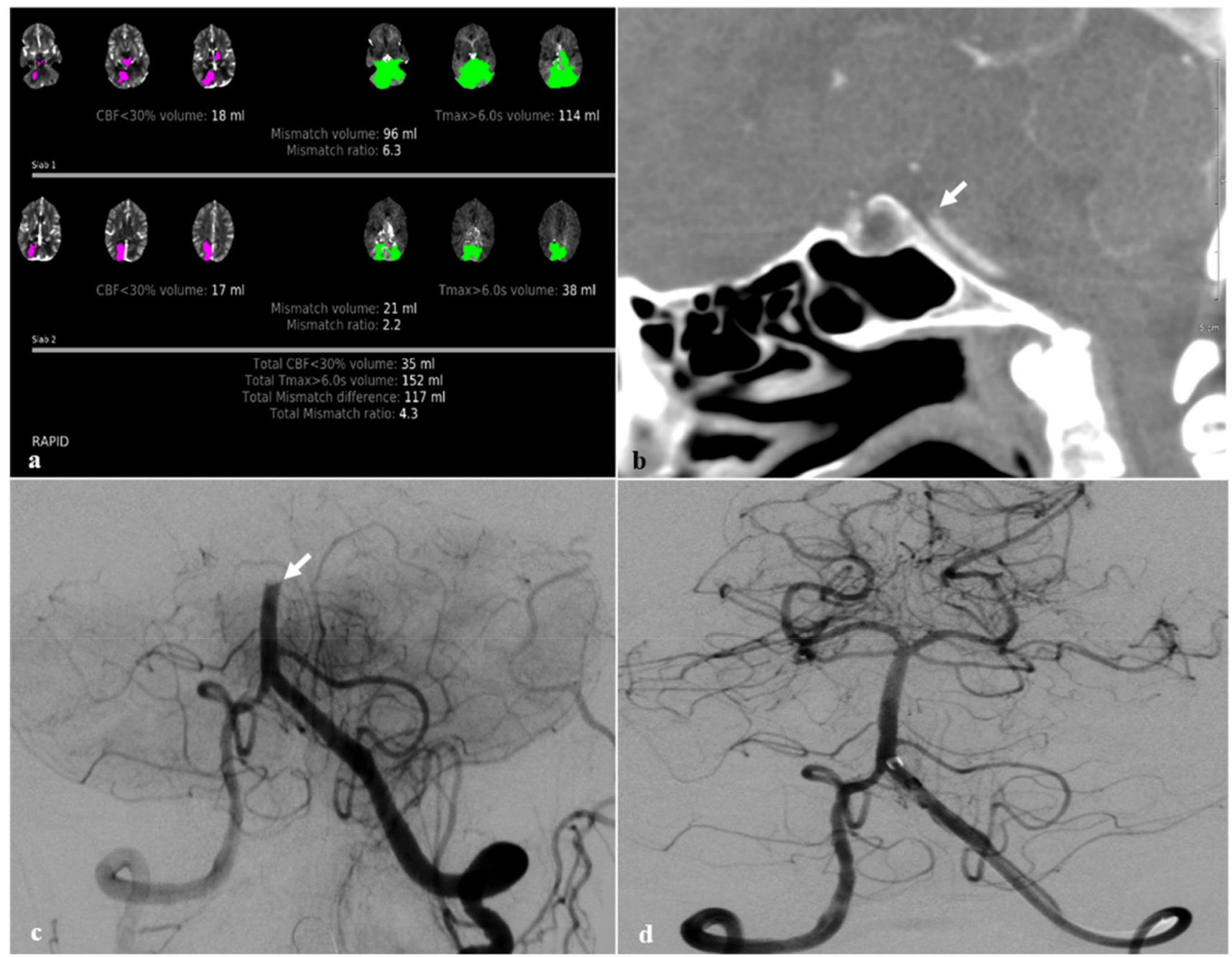

Fig. 1 A 75-year-old female with multiple comorbidities; a CT perfusion demonstrates a core infarction of $35 \mathrm{ml}$ and mismatch ration of 4.3. b CTA shows occlusion of the distal basilar artery

(arrow). c Left vertebral angiogram again reveals basilar artery occlusion. d Post thrombectomy angiogram reveals TICI3 perfusion 
Table 1 Patient demographics, clinical presentations, laboratory work-up, endovascular and clinical outcomes

\begin{tabular}{|c|c|c|c|}
\hline Characteristics & Patient 1 & Patient 2 & Patient 3 \\
\hline Demographics & 75 & 71 & 47 \\
\hline \multicolumn{4}{|l|}{ Age } \\
\hline Gender & $\mathrm{F}$ & $\mathrm{F}$ & $\mathrm{F}$ \\
\hline \multicolumn{4}{|l|}{ Comorbidities } \\
\hline & $\begin{array}{l}\text { HTN, HLD with left carotid } \\
\text { endarterectomy 2020, new A-fib } \\
\text { with RVR }\end{array}$ & $\begin{array}{l}\text { HTN, CAD s/p CABG 2012, HFrEF, } \\
\text { asthma, DM type II }\end{array}$ & None \\
\hline \multicolumn{4}{|l|}{ Symptoms/presentation } \\
\hline $\begin{array}{l}\text { COVID related symptoms } \\
\text { before presentation }\end{array}$ & $\begin{array}{l}\text { Intermittent chest tightness, } \\
\text { dyspnea on exertion, dizziness }\end{array}$ & None & Cough, shortness of breath \\
\hline $\begin{array}{l}\text { Interval between onset of } \\
\text { COVID symptoms and } \\
\text { stroke onset }\end{array}$ & 1 week & Not applicable & 4 days \\
\hline Symptoms on presentation & $\begin{array}{l}\text { Syncope, loss of consciousness } \\
15 \mathrm{~h} \text { after initial presentation }\end{array}$ & $\begin{array}{l}\text { Left sided weakness and left facial } \\
\text { droop, altered mental status }\end{array}$ & $\begin{array}{l}\text { Right sided weakness, left gaze } \\
\text { deviation, loss of } \\
\text { consciousness }\end{array}$ \\
\hline $\begin{array}{l}\text { Respiratory status during } \\
\text { hospitalization }\end{array}$ & $\begin{array}{l}\text { Acute hypoxemic respiratory } \\
\text { failure secondary to COVID-19 } \\
\text { pneumonia requiring intubation }\end{array}$ & $\begin{array}{l}\text { Severe respiratory distress secondary to } \\
\text { COVID-19 pneumonia shortly after } \\
\text { hospitalization requiring intubation }\end{array}$ & $\begin{array}{l}\text { Acute hypoxemic respiratory } \\
\text { failure secondary to COVID- } \\
19 \text { pneumonia requiring } \\
\text { intubation }\end{array}$ \\
\hline \multicolumn{4}{|l|}{ Initial management } \\
\hline Symptoms to door time & Unknown & Unknown & $40 \mathrm{~min}$ \\
\hline tPA & Ineligible & Ineligible & Yes \\
\hline Door to treatment time & $15 \mathrm{~h}$ & $80 \mathrm{~min}$ & $159 \mathrm{~min}$ \\
\hline \multicolumn{4}{|l|}{ Laboratory findings } \\
\hline PT/INR & $10.7 / 1.03$ & $11.8 / 1.14$ & $10.9 / 1.05$ \\
\hline APTT & 29 & 26.5 & 21.8 \\
\hline $\begin{array}{l}\text { D- } \\
\text { dimer(normal }<0.50 \mathrm{mg} / \\
\mathrm{L})\end{array}$ & 8.21 & 16.77 & 2.47 \\
\hline $\begin{array}{l}\text { C-reactive protein } \\
(\text { normal }<5 \mathrm{mg} / \mathrm{L})\end{array}$ & & 95 & 52.9 \\
\hline $\begin{array}{l}\text { Interleukin-6 } \\
(\text { normal }<6)\end{array}$ & & & 8 \\
\hline LDH (140-271 U/L) & & 325 & \\
\hline Ferritin (11-306.8 ng/ml) & & 98.1 & 10.4 \\
\hline $\begin{array}{l}\text { Troponin I (range } \\
3-17 \mathrm{ng} / \mathrm{L})\end{array}$ & 23 & 25 & \\
\hline $\begin{array}{l}\text { Antithrombin III activity } \\
(78-130)\end{array}$ & & $92 \%$ & \\
\hline $\begin{array}{l}\text { Fibrinogen }(186-466 \mathrm{mg} / \\
\text { dL) }\end{array}$ & & 600 & \\
\hline $\begin{array}{l}\text { Von-willebrand antigen } \\
(60-153)\end{array}$ & & $>300 \%$ & \\
\hline $\begin{array}{l}\text { Cardiolipin IgM } \\
(\text { normal }<15)\end{array}$ & & $20.30 \%$ & \\
\hline \multicolumn{4}{|l|}{ Stroke scale rating } \\
\hline NIHSS at onset & 40 & 12 & 17 \\
\hline \multicolumn{4}{|l|}{ Imaging findings } \\
\hline CTA findings & Occlusion distal basilar artery & $\begin{array}{l}\text { Occlusion of right inferior M2 and } \\
\text { paucity of the branches distally }\end{array}$ & $\begin{array}{l}\text { Occlusion of distal M1 segment } \\
\text { of left MCA }\end{array}$ \\
\hline CT perfusion findings & $\begin{array}{l}35 \mathrm{ml} \text { Core infarct in the right } \\
\text { PCA territory }\end{array}$ & $\begin{array}{l}58 \mathrm{ml} \text { Core infarct in right } \mathrm{MCA} \\
\text { territory }\end{array}$ & $\begin{array}{l}37 \text { ml Core infarct in left MCA } \\
\text { territory }\end{array}$ \\
\hline
\end{tabular}


Table 1 continued

\begin{tabular}{llll}
\hline Characteristics & Patient 1 & Patient 2 & Patient 3 \\
\hline $\begin{array}{l}\text { Intervention and outcome } \\
\begin{array}{c}\text { Mechanical thrombectomy } \\
\text { procedure and outcome }\end{array}\end{array}$ & TICI3 & TICI2b & TICI2b \\
$\begin{array}{l}\text { Clinical outcome } \\
\text { Death d/t cardiac arrest from } \\
\text { hypoxemic respiratory failure } \\
\text { secondary to COVID-19 } \\
\text { pneumonia }\end{array}$ & $\begin{array}{c}\text { Persistent neurological deficit of left } \\
\text { neglect and left hemiparesis }\end{array}$ & $\begin{array}{c}\text { Persistent aphasia, weakness, } \\
\text { apraxia and imbalance, } \\
\text { dysphagia requiring PEG for } \\
\text { feeding }\end{array}$ \\
$\begin{array}{l}\text { Score on mRS scale at } \\
\text { final follow-up }\end{array}$ & 6 & 4 & 5
\end{tabular}

$E R$ emergency room, $H T N$ hypertension, $H L D$ hyperlipidemia, A-Fib atrial fibrillation, $R V R$ rapid ventricular response, $C A D$ coronary artery disease, $C A B G$ coronary artery bypass grafting, $H F r E F$ Heart failure with reduced ejection fraction, $D M$ diabetes mellitus, $t P A$ tissue plasminogen activator, $P T$ prothrombin time, $I N R$ international normalized ratio, APTT activated partial thromboplastin time, $L D H$ lactate dehydrogenase, $M C A$ middle cerebral artery, $P E G$ percutaneous endoscopic gastrostomy, $m R S$ Modified Rankin Scale, NIHSS National Institute of Health Stroke Scale

\section{Literature Search}

We performed a literature research using the PubMed search engine on September 1st, 2020 using different combinations of the keywords COVID-19, SARS-CoV-2, stroke, large vessel occlusion and thrombectomy. Case series and treatment arms of observational studies were included. Studies that included COVID-19 negative patients and non-LVO pathologies were excluded. Patient's demographics, comorbidities, anatomic thrombus location, NIHSS at presentation and at $24 \mathrm{~h}$, angiographic outcome via the thrombolysis in cerebral infarction (TICI) scale, thrombectomy technical details, and mRS.

\section{Results}

\section{Patient Demographics}

In our series, we identified 3 patients (mean age $64.3 \pm 15.1$ ) with findings consistent with acute stroke on non-contrast head CT, followed by CTA head and CT perfusion studies (An example is demonstrated Fig. 1). All the 3 patients had a sizeable ischemic penumbra and were deemed candidates for EVT according to Endovascular Therapy Following Imaging Evaluation for Ischemic Stroke 3 (DEFUSE 3) criteria [13]. Two patients had anterior circulation LVO and one patient with posterior circulation LVO. Clinical presentation, treatment and outcome are detailed in (Table 1).

A total of 635 abstracts were identified from the literature search, from which 35 were identified for detailed review. Eight studies, including our case series, consisting of 73 patients were included for final analysis (Table 2). The average age of the included patients was 62.2 years,
$67.6 \%$ of whom were male. All but one study included demographic data regarding vascular comorbidities. Of these, hypertension was the most prevalent $(59.7 \%$, $n=43)$, followed by diabetes $(30.6 \%, n=22)$, atrial fibrillation (18.5\%), and hyperlipidemia (15.4\%). Six studies described the basic anatomic location of cerebral thrombus location, $65.7 \%(n=48)$ of which involved the anterior circulation. Involvement of the M1 segment was most commonly reported (53.8\%). Involvement of multiple vascular territories was noted in $34.6 \%$ of cases. Carotid involvement occurred in $19.2 \%$ of cases. The mean NIHSS at presentation was $20.4(12-40)$.

\section{Intervention}

In total, $47.9 \%(n=35)$ of patients received tPA and $89 \%$ $(n=65)$ underwent endovascular thrombectomy. Four studies describing 42 patients provided technical EVT details. The most utilized methods were the ADAPT technique $(40.5 \%, n=17)$ and stent-aspiration combination $(33.3 \%, n=14)$. Suction aspiration only and stent retrieval were used as primary techniques in $16.7 \%(n=7)$ and $9.5 \%$ patients $(n=4)$, respectively (Table 3 ).

\section{Outcomes}

TICI $\geq 2 \mathrm{~b}$ was reported in $83.1 \%(n=54)$ of cases. The mean NIHSS at $24 \mathrm{~h}$ after presentation (documented in three studies) was 20 (12-25), representing no significant difference compared to NIHSS at presentation. Six patients were reported to have early cerebral re-occlusion and cerebral hemorrhage occurred in three patients during the post-procedural period. In-hospital mortality was reported in $28.8 \%(n=15)$ of patients (Table 3$)$. 
Table 2 Pooled data: patient demographics, treatments, neurological outcomes and complications

\begin{tabular}{|c|c|c|c|c|c|c|c|c|c|}
\hline & $\begin{array}{l}\text { Wang } \\
\text { et al. } \\
{\left[16^{\bullet}\right]}\end{array}$ & $\begin{array}{l}\text { Sierra-Hidalgo } \\
\text { et al. [25] }\end{array}$ & $\begin{array}{l}\text { Escalard } \\
\text { et al. [20] }\end{array}$ & $\begin{array}{l}\text { Escalard } \\
\text { et al. [26] }\end{array}$ & $\begin{array}{l}\text { Pop } \\
\text { et al. } \\
{[27]}\end{array}$ & $\begin{array}{l}\text { Valderrama } \\
\text { et al. [28] }\end{array}$ & $\begin{array}{l}\text { Yang } \\
\text { et al. } \\
\text { [29] }\end{array}$ & $\begin{array}{l}\text { Current } \\
\text { case series }\end{array}$ & Total (\%) \\
\hline \multicolumn{10}{|l|}{ Demographics } \\
\hline Patients, $n$ & 5 & 8 & 10 & 12 & 13 & 1 & 21 & 3 & 73 \\
\hline $\begin{array}{l}\text { Mean age } \\
\text { (years) }\end{array}$ & 52.8 & 68.5 & 59.5 & 60.1 & 78 & 52 & 62.3 & 64.3 & 62.2 \\
\hline Male, $n$ & - & 7 & 8 & 10 & 5 & 1 & 15 & 0 & 46 \\
\hline Female, $n$ & - & 1 & 2 & 2 & 8 & 0 & 6 & 3 & 22 \\
\hline \multicolumn{10}{|l|}{ Comorbidities } \\
\hline $\mathrm{DM}, n$ & 1 & 3 & 4 & 5 & 2 & - & 6 & 1 & 22 \\
\hline $\mathrm{HTN}, n$ & 2 & 5 & 5 & 5 & 8 & - & 16 & 2 & 43 \\
\hline HLD, $n$ & 0 & & 3 & 3 & 3 & - & 0 & 1 & 10 \\
\hline $\begin{array}{l}\text { Atrial } \\
\text { fibrillation, } n\end{array}$ & & 1 & 1 & 1 & & - & 6 & 1 & 10 \\
\hline \multicolumn{10}{|l|}{$\begin{array}{r}\text { Thrombus } \\
\text { location }\end{array}$} \\
\hline $\begin{array}{l}\text { Anterior } \\
\text { circulation, } \\
n(\%)\end{array}$ & 5 & 5 & 9 & 12 & 8 & 0 & 13 & 2 & $54(74)$ \\
\hline $\begin{array}{l}\text { Posterior } \\
\text { Circulation, } \\
n(\%)\end{array}$ & 1 & 4 & 1 & - & 5 & 0 & - & 1 & $12(30)$ \\
\hline $\begin{array}{l}\text { Multiple } \\
\text { territories, } \\
n(\%)\end{array}$ & 1 & 1 & 5 & 6 & - & 1 & - & 0 & $14(35.9)$ \\
\hline \multicolumn{10}{|l|}{ NIHSS } \\
\hline $\begin{array}{l}\text { Presentation, } \\
\text { mean (range) }\end{array}$ & $\begin{array}{l}27 \\
(10-29)\end{array}$ & $27(16-39)$ & 22 (19-26) & $19(18-24)$ & 13 & 20 & 12 & $23(12-40)$ & $\begin{array}{l}\text { Average of } \\
20.4 \\
(7-40)\end{array}$ \\
\hline $\begin{array}{l}24 \mathrm{~h}, \text { mean } \\
\text { (range) }\end{array}$ & - & $25(20-42)$ & $25(20-42)$ & - & - & - & 10 & - & 20 \\
\hline \multicolumn{10}{|l|}{ Treatment } \\
\hline tPA, $n$ & 5 & 0 & 5 & 8 & 4 & 1 & 11 & 1 & 35 (47.9) \\
\hline $\mathrm{EVT}, n$ & 5 & 0 & 10 & 12 & 13 & 1 & 21 & 3 & $65(89)$ \\
\hline \multicolumn{10}{|l|}{$\begin{array}{l}\text { Angiographic } \\
\text { outcome }\end{array}$} \\
\hline $\mathrm{TICI} \geq 2 \mathrm{~b}, n$ & 3 & - & 9 & 11 & 10 & 0 & 18 & 3 & $54(83.1)$ \\
\hline \multicolumn{10}{|l|}{ Clinical outcome } \\
\hline Death, $n$ & 3 & 4 & 6 & 5 & 2 & 0 & - & 1 & $15(28.8)$ \\
\hline $\begin{array}{l}\text { Early cerebral re- } \\
\text { occlusion, } n\end{array}$ & 0 & 0 & 4 & 0 & 1 & 0 & 0 & 1 & $6(8.2)$ \\
\hline $\begin{array}{l}\text { Post-procedural } \\
\text { hemorrhage, } n\end{array}$ & 0 & 0 & 0 & 0 & 0 & 0 & 3 & 0 & $3(4.1)$ \\
\hline
\end{tabular}

\section{Discussion}

The COVID-19 pandemic has demonstrated a direct and indirect impact on the occurrence and presentation of acute cerebrovascular disease. The known associated prothrombotic state leading to arterial and venous thrombosis has contributed to stroke being the most commonly reported neurological complication [4, 6]. Using meta-analytic methodology to analyze outcomes data following EVT, our study highlights the various challenges of treating COVID19 patients presenting with stroke. 
Table 3 Summary of patient characteristics and outcomes

\begin{tabular}{ll}
\hline Demographics & Total \\
\hline Patients, $n$ & 73 \\
Mean age (years) & 62.2 \\
Male, $n$ & 46 \\
Female, $n$ & 22 \\
Comorbidities & \\
DM, $n$ & 22 \\
HTN, $n$ & 43 \\
HLD, $n$ & 10 \\
Atrial fibrillation, $n$ & 10 \\
Thrombus location & \\
Anterior circulation, $n(\%)$ & $54(74)$ \\
Posterior circulation, $n(\%)$ & $12(30)$ \\
Multiple territories, $n(\%)$ & $14(35.9)$ \\
NIHSS & \\
Presentation, mean (range) & $20.4(12-40)$ \\
24 h, mean (range) & 20 \\
Treatment & \\
tPA, $n$ (\%) & $35(47.9)$ \\
EVT, $n$ (\%) & $65(89 \%)$ \\
Angiographic outcome & \\
TICI $\geq 2 b, n(\%)$ & $6(9.2)$ \\
Clinical outcome & $3(5.6)$ \\
mRS 6 (death), $n(\%)$ & \\
Early cerebral re-occlusion, $n(\%)$ & \\
Post-procedural hemorrhage, $n(\%)$ & \\
\hline
\end{tabular}

Although COVID-19 related LVO has been reported in young patients less than 50 years old, the mean age of this patients' pool was 62.2 years and is comparable to the mean of 68 years in pre-pandemic reports $[8,14,15,16 \cdot$, 17]. This review found the NIHSS at presentation among COVID-19 patients is typically moderate to severe with a mean of 20.4 (range 7-40), consistent with a recent systematic review that reported a mean of 19 [18•]. In the series of patients from our institution, the two patients with anterior circulation LVO had NIHSS of 12 and 17 comparable to large-scale EVT trials who report an NIHSS range of 14-20 (mean of 17) [17]. This contrasts to the NIHSS of 40 in the patient with basilar occlusion, which was reported in $12.5 \%$ of the overall included patient pool. Re-evaluation of the NIHSS at $24 \mathrm{~h}$ after presentation, which was reported in three of the eight studies, demonstrated no significant difference with the NIHSS at presentation, suggesting EVT has minimal effect in the acute phase $\left[19,20^{\bullet}\right]$.
A small but significant proportion of the patients who underwent EVT (8\%) had early proximal arterial re-occlusion after a successful thrombectomy. Overall post procedure intracerebral hemorrhage was $4 \%$, which is comparable to previous EVT trials [17]. Though successful revascularization (TICI $\geq 2$ b) was achieved in $83 \%$ of patients regardless of technique used, the in-hospital mortality rate was high at $28.8 \%$ compared to $15.3 \%$ among non-COVID-19 patients [17]. In our series of patients, persistent neurological deficits were noted in two patients and one patient ultimately died from stroke and COVID-19 related respiratory complications. Despite a high proportion of successful angiographic results, these relatively poor outcomes compared to non-COVID-19 stroke patients may be attributed to differences in clot composition, with an increased tendency for clot fragmentation and migration that results in microemboli as described by Wang et al. [16•]. The sequalae of such microemboli are further exacerbated by the severity of the underlying COVID-19 respiratory disease that in conjunction with stroke indicates a worse overall prognosis [6].

Recent literature has reported the incidence of stroke among COVID-19 patients to range between 1.1 and 5.7\% $[5,6,9,21,22]$. However, as patients with multiple cardiovascular risk factors are significantly more likely to develop severe COVID-19 disease as well as acute cerebrovascular disease, the association between COVID-19 and stroke is complex [23, 24]. Future research that employ multi-institutional cohorts of larger patient populations will be required to more clearly elucidate the relationship between comorbidities and LVOs related to COVID-19.

Our results are subject to inherent limitations of the retrospective nature of case series and case reports, including significant heterogeneity of included studies. Furthermore, several of the studies included in this systematic review failed to report relevant variables such as NIHSS at $24 \mathrm{~h}$ and mRS, and most of these were reported on a mean basis making it difficult to evaluate the progression or outcome of each patient. Future studies with a larger cohort and more detailed long-term neurological follow-up are required.

\section{Conclusion}

This systematic literature analysis demonstrates overall poor outcomes and high mortality in COVID-19 patients presenting with stroke despite angiographically successful EVT of LVOs in the majority of patients. An unusual incidence of early intracerebral proximal arterial re-occlusion and propensity for clot fragmentation and microemboli may be significant contributing factors. 


\section{Compliance with Ethical Guidelines}

Conflict of interest No conflicts of interest to declare.

Disclosure No authors have financial relationships relevant to this article to disclose.

\section{References}

Papers of particular interest, published recently have been highlighted as:

- Of importance

1. Yan Y, Shin WI, Pang YX, Meng Y, Lai J, You C, Zhao H, Lester E, Wu T, Pang CH. The first 75 days of novel coronavirus (SARS-CoV-2) outbreak: recent advances, prevention, and treatment. Int J Environ Res Public Health. 2020;17(7):2323.

2. Clinical characteristics of 113 deceased patients with coronavirus disease 2019: retrospective study. BMJ (Clin Res Ed) 2020;368:m1295.

3. Guan WJ, Ni ZY, Hu Y, Liang WH, Ou CQ, He JX, Liu L, Shan H, Lei CL, Hui DSC, Du B, Li LJ, Zeng G, Yuen KY, Chen RC, Tang CL, Wang T, Chen PY, Xiang J, Li SY, Wang JL, Liang ZJ, Peng YX, Wei L, Liu Y, Hu YH, Peng P, Wang JM, Liu JY, Chen Z, Li G, Zheng ZJ, Qiu SQ, Luo J, Ye CJ, Zhu SY, Zhong NS. Clinical characteristics of coronavirus disease 2019 in China. N Engl J Med. 2020;382(18):1708-20.

4. Lodigiani C, Iapichino G, Carenzo L, Cecconi M, Ferrazzi P, Sebastian T, Kucher N, Studt JD, Sacco C, Alexia B, Sandri MT, Barco S. Venous and arterial thromboembolic complications in COVID-19 patients admitted to an academic hospital in Milan, Italy. Thromb Res. 2020;191:9-14.

5. Klok FA, Kruip M, van der Meer NJM, Arbous MS, Gommers D, Kant KM, Kaptein FHJ, van Paassen J, Stals MAM, Huisman $\mathrm{MV}$, Endeman $\mathrm{H}$. Incidence of thrombotic complications in critically ill ICU patients with COVID-19. Thromb Res. 2020;191:145-7.

6. Jain R, Young M, Dogra S, Kennedy H, Nguyen V, Jones S, Bilaloglu S, Hochman K, Raz E, Galetta S, Horwtiz L. COVID19 related neuroimaging findings: a signal of thromboembolic complications and a strong prognostic marker of poor patient outcome. J Neurol Sci. 2020;414:116923.

7. Markus HS, Brainin M. COVID-19 and stroke-a global world stroke organization perspective. Int J Stroke. 2020;15(4):361-4.

8. Kerleroux B, Fabacher T, Bricout N, Moïse M, Testud B, Vingadassalom S, Ifergan $\mathrm{H}$, Janot $\mathrm{K}$, Consoli A, Ben Hassen W, Shotar E, Ognard J, Charbonnier G, Lallinec V, Guédon A, Bolognini F, Marnat G, Forestier G, Rouchaud A, Pop R, Raynaud N, Zhu F, Cortese J, Chalumeau V, Berge J, Escalard S, Boulouis G. Mechanical thrombectomy for acute ischemic stroke amid the COVID-19 outbreak: decreased activity, and increased care delays. Stroke. 2020;51(7):2012-7. https://doi.org/10.1161/ STROKEAHA.120.030373.

9. Merkler AE, Parikh NS, Mir S, Gupta A, Kamel H, Lin E, Lantos J, Schenck EJ, Goyal P, Bruce SS, Kahan J, Lansdale KN, LeMoss NM, Murthy SB, Stieg PE, Fink ME, Iadecola C, Segal AZ, Campion TR, Diaz I, Zhang C, Navi BB. Risk of ischemic stroke in patients with Covid-19 versus patients with influenza. JAMA. 2020. https://doi.org/10.1101/2020.05.18.20105494.

10. Khosravani H, Rajendram P, Notario L, Chapman MG, Menon BK. Protected code. Stroke. 2020;51(6):1891-5.
11. Leslie-Mazwi TM, Fargen KM, Levitt M, Derdeyn CP, Feske SK, Patel AB, Hirsch JA. Preserving access: a review of stroke thrombectomy during the COVID-19 pandemic. AJNR Am J Neuroradiol. 2020;41(7):1136-41.

12. Fraser JF, Arthur AS, Chen M, Levitt M, Mocco J, Albuquerque FC, Ansari SA, Dabus G, Jayaraman MV, Mack WJ, Milburn J, Mokin M, Narayanan S, Puri AS, Siddiqui AH, Tsai JP, Klucznik RP. Society of NeuroInterventional Surgery recommendations for the care of emergent neurointerventional patients in the setting of COVID-19. J Neurointerv Surg. 2020;12(6):539-41.

13. Albers GW, Marks MP, Kemp S, Christensen S, Tsai JP, OrtegaGutierrez S, McTaggart RA, Torbey MT, Kim-Tenser M, LeslieMazwi T, Sarraj A, Kasner SE, Ansari SA, Yeatts SD, Hamilton S, Mlynash M, Heit JJ, Zaharchuk G, Kim S, Carrozzella J, Palesch YY, Demchuk AM, Bammer R, Lavori PW, Broderick JP, Lansberg MG. Thrombectomy for stroke at 6 to 16 hours with selection by perfusion imaging. $\mathrm{N}$ Engl $\mathrm{J}$ Med. 2018;378(8):708-18.

14. Fifi JT, Mocco J. COVID-19 related stroke in young individuals. The Lancet Neurology. 2020;19(9):713-5.

15. Oxley TJ, Mocco J, Majidi S, Kellner CP, Shoirah H, Singh IP, De Leacy RA, Shigematsu T, Ladner TR, Yaeger KA, Skliut M, Weinberger J, Dangayach NS, Bederson JB, Tuhrim S, Fifi JT. Large-vessel stroke as a presenting feature of Covid-19 in the young. N Engl J Med. 2020;382(20):e60.

16. - Wang A, Mandigo GK, Yim PD, Meyers PM, Lavine SD. Stroke and mechanical thrombectomy in patients with COVID19: technical observations and patient characteristics, Journal of neurointerventional surgery 2020;12(7):648-53. This study detalis institutional experience with mechanical thrombectomies of COVID-19 patients and hypothesis of the propensity of the clots develop in these patients to cause dital emboli after treatment.

17. Goyal M, Menon BK, van Zwam WH, Dippel DW, Mitchell PJ, Demchuk AM, Dávalos A, Majoie CB, van der Lugt A, de Miquel MA, Donnan GA, Roos YB, Bonafe A, Jahan R, Diener HC, van den Berg LA, Levy EI, Berkhemer OA, Pereira VM, Rempel J, Millán M, Davis SM, Roy D, Thornton J, Román LS, Ribó M, Beumer D, Stouch B, Brown S, Campbell BC, van Oostenbrugge RJ, Saver JL, Hill MD, Jovin TG. Endovascular thrombectomy after large-vessel ischaemic stroke: a meta-analysis of individual patient data from five randomised trials. Lancet (London, England). 2016;387(10029):1723-31.

18. - Tan YK, Goh C, Leow AST, Tambyah PA, Ang A, Yap ES, Tu TM, Sharma VK, Yeo LLL, Chan BPL, Tan BYQ. COVID-19 and ischemic stroke: a systematic review and meta-summary of the literature. J Thromb Thrombolysis 2020;50(3):587-95. This study's pool data demonstrates the high mortality rate of COVID19 patients complicated by ischemic stroke.

19. Lapergue B, Lyoubi A, Meseguer E, Avram I, Denier C, Venditti L, Consoli A, Guedon A, Houdart E, Weisenburger-Lile D, Piotin M, Maier B, Obadia M, De Broucker T. Large vessel stroke in six patients following SARS-CoV-2 infection: a retrospective case study series of acute thrombotic complications on stable underlying atherosclerotic disease. Eur J Neurol. 2020;27(11):2308-11.

20. • Escalard S, Maïer B, Redjem H, Delvoye F, Hébert S, Smajda S, Ciccio G, Desilles JP, Mazighi M, Blanc R, Piotin M. Treatment of acute ischemic stroke due to large vessel occlusion with COVID-19: experience from Paris. Stroke 202;51(8):2540-3. This study details stroke characteristics in COVID-19 patients and compare them with non-COVID patients and includes pre and post thrombectomy neurologica status evaluated by NIHSS.

21. Li Y, Wang M, Zhou Y, Chang J, Xian Y, Mao L, Hong C, Shengcai C, Wang Y, Wang H, Li M, Jin H, Hu B. Acute cerebrovascular disease following COVID-19: a single center, 
retrospective, observational study. SSRN Electron J. 2020;5(3):279-84.

22. Mao L, Jin H, Wang M, Hu Y, Chen S, He Q, Chang J, Hong C, Zhou Y, Wang D, Miao X, Li Y, Hu B. Neurologic manifestations of hospitalized patients with coronavirus disease 2019 in Wuhan. China, JAMA Neurol. 2020;77(6):683-90.

23. Du RH, Liang LR, Yang CQ, Wang W, Cao TZ, Li M, Guo GY, Du J, Zheng CL, Zhu Q, Hu M, Li XY, Peng P, Shi HZ. Predictors of mortality for patients with COVID-19 pneumonia caused by SARS-CoV-2: a prospective cohort study. Eur Respir J. 2020;55(5):2000524.

24. Ruan Q, Yang K, Wang W, Jiang L, Song J. Clinical predictors of mortality due to COVID-19 based on an analysis of data of 150 patients from Wuhan, China. Intensive Care Med. 2020;46(5):846-8.

25. Sierra-Hidalgo F, Muñoz-Rivas N, Torres Rubio P, Chao K, Villanova Martínez M, Arranz García P, Martínez-Acebes E. Large artery ischemic stroke in severe COVID-19. J Neurol. 2020;267(12):3441-3.

26. Escalard S, Chalumeau V, Escalard C, Redjem H, Delvoye F, Hébert S, Smajda S, Ciccio G, Desilles JP, Mazighi M, Blanc R,
Maïer B, Piotin M. Early brain imaging shows increased severity of acute ischemic strokes with large vessel occlusion in COVID19 patients. Stroke. 2020;51(11):3366-70. https://doi.org/10. 1161/STROKEAHA.120.031011.

27. Pop R, Hasiu A, Bolognini F, Mihoc D, Quenardelle V, Gheoca R, Schluck E, Courtois S, Delaitre M, Musacchio M, Pottecher J, Chamaraux-Tran TN, Sellal F, Wolff V, Lebedinsky PA, Beaujeux R. Stroke thrombectomy in patients with COVID-19: initial experience in 13 cases. AJNR Am J Neuroradiol. 2020;41(11):2012-6.

28. Valderrama EV, Humbert K, Lord A, Frontera J, Yaghi S. Severe acute respiratory syndrome coronavirus 2 infection and ischemic. Stroke. 2020;51(7):e124-7.

29. Fatima N, Saqqur M, Qamar F, Shaukat S, Shuaib A. Impact of COVID-19 on neurological manifestations: an overview of stroke presentation in pandemic. Neurol Sci. 2020;41(10):2675-9.

Publisher's Note Springer Nature remains neutral with regard to jurisdictional claims in published maps and institutional affiliations. 